\title{
Marital Life - A Bliss or a Curse
}

\author{
Dr. Geetharamani Shanmugam
}

\begin{abstract}
In the present scenario of too many separations and divorces among the married couples, I thought, it would be of paramount importance and appropriate, to throw light on this subject "Marital Bliss" through an empirical study of observations and experiences. As a Social Scientist I have observed many married couples', attitude and behaviour and my experience with them motivated me to touch upon this sensitive subject. In order to save a marriage, it has to be nurtured well, like how a plant is nurtured by adding water and manure to grow. Marriage should never be taken for granted by both partners and there needs to be a sincere involvement and commitment from both partners. In this paper it has been discussed, the salient features to be followed for a marriage to be a bliss and not a curse.
\end{abstract}

Keywords - Bliss, Marriage, Marital Life, Salient Features.

\section{INTRODUCTION}

$\mathrm{M}$ ARITAL life is an important period in the life of any human being. A man or woman's life becomes completed only through marriage. A man or woman commands respect and dignity only if he or she is married, in many Societies. Even in the present changing social scenario also, marriage is considered an important and crucial life event for any human being. According to the dictionary the meaning of marriage is "The Legal Union of a man and woman to live together intimately life long and to have children". Marriage is a socially supported union involving two or more individuals in what is regarded as a stable enduring arrangement based atleast in part on a sexual bond of some kind. Though marriage ceremonies and roles may differ from one society to another, marriage is considered as a cultural event universally, which means that it is present as a social institution in all cultures.

\section{II.THE SOCIAL CHARACTERISTICS OF MARRIAGE}

A marriage is often based on a romantic relationship, though it is not always the case. It signals a sexual relationship between two people. A marriage however does not simply exist between the married partners, but rather is codified as a social institution in legal, economic, social and spiritual /religious ways. In many societies including the western world and the United states, marriage is widely considered the basis and foundation for family. That is why a marriage is often greeted socially with immediate expectation that the couple will produce children. Because a marriage is recognized by

Dr.Geetharamani Shanmugam, Subramaniam Arts \& Science College Namakkal, Tamilnadu, ,India (geethasm107@gmail.com). law, by the economy, socially and by religious institutions, a dissolution or divorce of marriage must in turn involve a dissolution of the marriage relationship in all these realms.

\section{The SOCIAL Functions Of MARRIAGE}

Marriage has several functions that are important with in the societies and cultures where in the marriage takes place. Most commonly marriage dictates the roles that spouses play in each other's lives, in the family and in society at large. American sociologist Talcott Parsons wrote on the topic and specified a theory of roles with in a marriage and household, where in wife/ mother plays the expressive role of a caregiver who takes care of socialization and emotional needs of others in the family, while the husband/ father is responsible for the task role of earning money to support the family. But in the changing scenario of the society women also do play the task role of earning and supporting financially in addition to the care giving role. In keeping with this thinking a marriage often serves the function of dictating the social states of the spouses and the couples and of creating a hierarchy of power between the couples. This hierarchy of power which leads to ego to both the partners, sometimes lead to marital conflict and end up in separation, divorce, and children become the victims of such incidents and they have to bear the brunt of it. The consequence of marital life is not always pleasant and desirable. In India there is an old adage which says that "Marriage is a 1000 years old crop" and hence it has to be nurtured well inorder to save it. How we nurture a plant by adding water and manure, we need to grow the plant of marriage by adding various measures which are discussed below.

\section{OBJECTIVES}

The purpose of this study are:

1) To elicit the reasons for the marital discord and disharmony

2) To suggest the ways and means to mitigate the problems and to save the marriage

There are seven salient features which need to be followed or practised by both the marital partners, if they want their marital life to be a bliss and not a curse.

1. Accepting your partners as they are

2. Not nagging

3. Not criticizing

4. Giving honest appreciation

5. Paying little attention

6. Being Courteous 


\section{Being good partners in the sexual life}

\section{Accepting your partner as they are}

First of all both wife and husband should accept each other as they are with all their negative and positive qualities and habits. Some wife and husband do have some peculiar characters which should not be viewed as a mockery thing by both and they should be endured and tolerated, as long as they do not pose as big problems to their lives. There may be initial difficulties in accepting each other as they are, with their inherent traits, habits and behavior, especially if they are not as per their expectations. But if you want to strengthen the institution of marriage, it has to be done sincerely. Once you start accepting your partners as they are, then gradually you would start caring them and liking them. Once you start liking them you would start tolerating whatever they do and with sincere interest and utmost care you can slowly try to correct them. If your attempt is sincere and genuine then your partner will turn out to be of your desired person.

\section{No nagging}

Some husbands and wives do have the habit of constantly nagging their partners whatever they do. They will keep on complaining and fault finding whatever they do. This habit will mar your relationship in the long run. The famous men of history Napoleon III of France, nephew of Napoleon Bonaparte, Leo Tolstoy and Abraham Lincoln had a miserable marital life due to their respective wives' constant nagging.

\section{No criticizing}

Dorothy Dix, America's authority on the causes of marital happiness, declared that one of the causes of failures

of marriage, is criticism. If you want your home life happy never criticise. Some human beings do have the nasty habit of always criticising their partners, that too infront of others.

\section{Paying little attention}

Paying little attention is indicating the person you love, that you are in her/his thoughts, you want to please her/him and that her/his happiness and welfare are of utmost importance to you. Especially to women paying little attention means a lot. She wants her husband's attention by way of his admiring, appreciating whatever she does. Wishing and gifting for her birthdays and anniversaries carry lot of weight and will go a long way in the marital life.

\section{Giving honest appreciation}

Give the devil its due. Make honest and sincere appreciation to your partners when they do something nice. That serves as a fillip and will bring out many positive consequences. Paul Popenoe the then director of the institute of family Relations in Los Angeles has said that "Most men when seeking wives are not looking for executives but for someone with allure and willingness to flatter their vanity and make them feel superior". Especially this is all the more true in our country where there is a prevailing patriarchal and patrilineal social structure and where the man's ego always wants to be boosted up. This does apply to women too. Whenever a wife cooks some nice food it is failed to be appreciated by the husband, it is just being taken for granted. If a husband appreciates her cooking even she makes an ordinary thing, then her happiness knows no bounds.

\section{Being courteous}

Courtesy, says Henry Clay Risner, "Is that quality of heart that overlooks the broken gate and calls attention to the flowers in the yard beyond the gate". Courtesy is just as important to marriage as oil is to the motor. This courtesy is the missing factor in many families, the truth is that the only people who are discourteous to us are our own households, by saying mean, insulting and hurting things. Many men who are very polite and courteous to their customers or to their business partners, could think nothing than yelling at their wives. How we are so courteous to the strangers, the same way let us try to be courteous to our own life partners. In this courtesy aspect alone consider them as strangers and try to be courteous.

\section{Being a good partner on the sexual side of marriage}

According to Dr. Paul Popenoe as head of the institute of family Relations in Los Angles, one of the failures of marriage, is sexual maladjustment. All authorities on divorce agree upon the absolute necessity for sexual compatibility. The famous psychologist John B. Watson says "Sex, is admittedly the most important subject in Life. It is admittedly the thing which causes the most ship-wrecks in the happiness of men and women". Dr. Butter Field says "Sex is one of the many satisfactions in married life, but unless this relationship is right, nothing else can be right. Both partners must discuss freely about sex without any inhibitions. Do not be matrimonial illiterates and get the thorough knowledge about this, by reading some good books on this subject, which may enable you to clear your doubts and enlighten you on this matter by comprehensive explanations and clarifications. Sexual dysfunction among the youngsters, is a common issue nowadays. Occurrence of diabetics at the young age and the stress of professional and family life take a toll on the sexual lives of the youngsters considerably. Impotence and frigidity are common sexual problems among the young partners which are purely psychological and could be treated at the early stages, by seeking medical interventions. Hence if youngsters do have such issues, they should feel free to consult a doctor, preferably sexologist without any delay otherwise their marital life will be at stake. ed.

\section{V.CONCLUSION}

If the above mentioned procedures and methods are followed with interest and involvement by both the marital partners, marriage will be a bliss and not a mess or curse. 